Article

\title{
Land Use Changes and Their Driving Forces in a Debris Flow Active Area of Gansu Province, China
}

\author{
Songtang $\mathrm{He}^{1,2,3} \mathbb{1}^{\mathbb{D}}$, Daojie Wang ${ }^{1,2, *}$, Yong $\mathrm{Li}^{1,2}$ and Peng Zhao ${ }^{1,2,3}$ \\ 1 Key Laboratory of Mountain Hazards and Earth Surface Processes, Chinese Academy of Sciences, \\ Chengdu 610041, China; hst1529568372@126.com (S.H.); ylie@imde.ac.cn (Y.L.); dilikexuezp@126.com (P.Z.) \\ 2 Institute of Mountain Hazards and Environment, Chinese Academy of Sciences, Chengdu 610041, China \\ 3 University of Chinese Academy of Sciences, Beijing 100049, China \\ * Correspondence: wangdj@imde.ac.cn
}

Received: 27 June 2018; Accepted: 2 August 2018; Published: 4 August 2018

check for updates

\begin{abstract}
Land use change is extremely sensitive to natural factors and human influence in active debris flow. It is therefore necessary to determine the factors that influence land use change. This paper took Wudu District, Gansu Province, China as a study area, and a systemic analysis of the transformational extent and rate of debris flow waste-shoal land (DFWSL) was carried out from 2005 to 2015. The results show that from 2005 to 2015, cultivated land resources transformed to other types of land; cultivated lands mainly transformed to grassland from 2005 to 2010 and construction land from 2010 to 2015. Moreover, the growth rate of construction land from 2005 to 2010 was only $0.11 \%$, but increased to $6.87 \%$ between 2010 and 2015. The latter is more than 60 times the former. This increase was brought about by natural disasters (debris flow, earthquakes, and landslides) and anthropogenic factors (national policies or strategies), which acted as driving forces in debris flow area. The former determines the initial use type of the DFWSL while the latter only affects the direction of land use and transformation.
\end{abstract}

Keywords: debris flow waste-shoal land; land use and transformation; driving forces analysis; territorial development; marginal land resources

\section{Introduction}

Land use is an anthropogenic activity in which the natural characteristics of the land are identified, and bio-technological means are adopted to periodically harness and manage the land for socioeconomic benefits [1]. Land cover refers to the natural and biophysical properties of the Earth's surface [2]. Land use and land cover changes result from interactions among socioeconomic, institutional, and environmental factors [3]. In 1995, the International Geosphere-Biosphere Program (IGBP) and the Human and Environmental Plan (HDP) jointly launched the land use and land cover change (LUCC) research program to further research on land use and transformation, especially with regard to global changes. Studies on LUCC over the past decades have focused on the analysis of factors driving land use, dynamic processes of land use, and the interrelation between land use and land cover changes [4-6]. Understanding the dynamic system of driving forces is key to revealing the sources of land use change. In the past, research has been conducted to understand the following: (1) Change in land cover due to human activities over the past 300 years; (2) anthropogenic factors influencing land use and transformation in different historical stages and geographic units [7-9]; (3) impact of land use and transformation on land cover over the next 50-100 years [10,11]; (4) impacts of anthropogenic and biophysical factors on the carrying capacities of different land types [12]; and (5) impacts of climate and global biogeochemistry on land use and land cover $[13,14]$. As urbanization prevails and the global population surges, the food supply is predicted to increase by $60 \%$ by 2050 [15], implying that the area 
of agricultural land (arable area) may require an increase of 10-26\% [16]. In extreme cases, farmland will need to increase by $42 \%$ and pastures by $15 \%$ to meet the growing demands [17]. This raises questions about the extent to which technology can help improve the capacity of land, how land can be utilized effectively, and whether current land resources will meet future demands [18].

Considering the above-mentioned scenarios, as well as intense human activities and severe natural disasters, the capacity of the available land resources (including cultivated land, forests, industrial and mining land, etc.) in ecologically fragile areas is likely to decrease. Moreover, the possibility of an increase in quality or quantity is limited. Additionally, ecological security serves as the core of land resource sustainability. Reshaping the relationship between land use and the ecological environment, and maintaining the renewability of land resources, are important for the restoration of damaged land ecosystems [19]. Consequently, in order to increase the available area, and to provide an opportunity to achieve a multi-win of soil and water conservation, environmental governance and economic development, research perspectives should shift toward exploring land resources that were previously deemed unavailable. Moreover, past studies have paid special attention to areas with vulnerable ecosystems [20,21] and especially those characterized by sensitivity and instability [22]. For instance, the successful management and use of desert lands in northwestern China [23], reuse of abandoned mining land [24], land development and use in karst areas [25], and the proper use of torrential floods in arid and semi-arid areas [26]. These lands are important reserves of resources and not only provide sufficient space for industrialization and urbanization but also work as effective buffers for ecological construction. Therefore, it is essential to address the dilemma of protecting cultivated land while pursuing development in mountainous regions [27]. To explore the possibilities of developing unused land in mountainous areas, this study focused on the use of debris flow waste-shoal land (DFWSL), cover changes in mountainous areas, and the driving forces behind these changes.

DFWSL is the products of debris flows, which frequently occur and generally develop in the lower reaches of valleys [28-32]. Some scholars refer to them as 'bajada' [33], 'floodplain', or 'alluvial fans' [34-36] because of their fan-shaped structures when formed [30,37,38]. Wang Daojie [39] pointed out that the raw debris flow fan is alkaline with unreasonable soil hierarchy (no clear plough layer, plow pan and subsoil) and poor physical structure (compact structure). The different textures can be further categorized as boulder clay, silty soil, and gravel. In addition, its organic content is under $1 \%$, and the contents of available nitrogen, phosphorus, as well as potassium, are presented in moderate levels or lower. Through soil improvement, the soil layer of the debris flow fan can reach $35 \mathrm{~cm}$, with a gravel content of only $1 \%$. The soil texture can also be significantly improved from silty soil to silty loam soil. Other scholars deemed that there were distinctive characteristics between the debris flow fan and other piedmonts, such as surface features, and the stratum. The sub-characteristics, such as the characters of grooving, dikes, ditches, and the shape or tip of the debris flow fan were also used to identify the debris flow fan (Figure 1a,b) $[30,37,38,40]$. Valley-type debris flow fans have features such as a gentle topography (about $5^{\circ}$ ), abundant water sources, convenient transportation, and easy access to irrigation [41]. Therefore, agricultural activities are carried out on some DFWSL, while some towns and villages are also built on the fans [31,42]. Additionally, some settlements also improve access to the fans to enable conversion to commercial or recreational sites with infrastructure like golf courses [43]. However, unlike conventional land resources, the use of DFWSL is subject to greater spatial-temporal variability [44-46]. Several studies have looked at dynamic land use and its driving forces; however, analyses of land use and transformation, as well as the driving forces in mudslide-prone areas are limited [47]. Additionally, land use is subject to limitations of the natural environment and intervention of human activities. Focusing on the driving forces behind use and transformation patterns is a major approach to elucidate the general relationship between the socioeconomic and natural environments $[48,49]$. Therefore, it is necessary to analyze the transformation of DFWSL as well as the driving forces behind the transformation to lay the foundation for balanced, efficient, and safe development and use of DFWSL. 


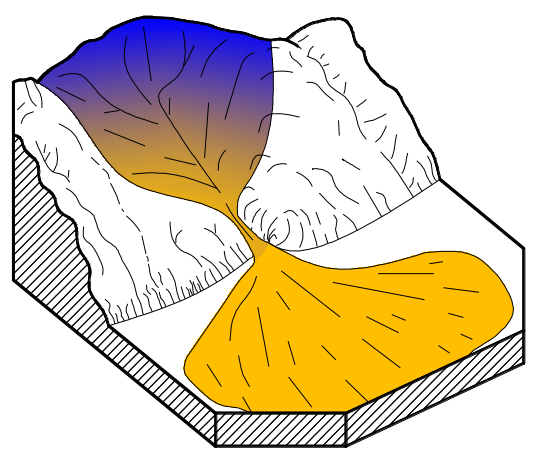

(a)

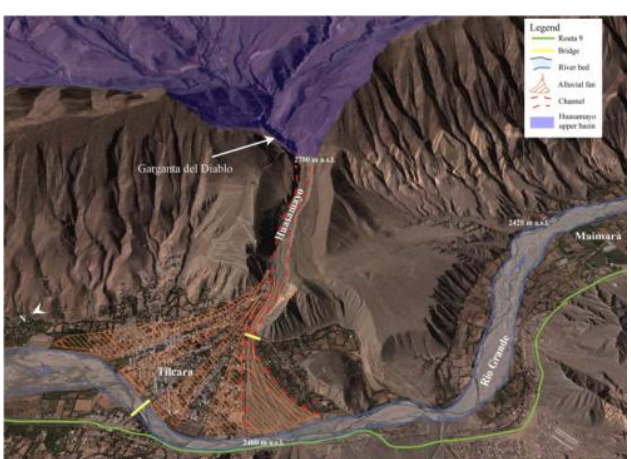

(b)

Figure 1. Various debris flow fans. (a) The original debris flow fan; (b) Tilcara alluvial fan in Argentina [31].

Land use in developed regions of western China has received significant attention [50-54]; however, the study of land use and driving forces in underdeveloped areas of western China, especially in ecologically fragile areas, requires further attention [20]. Debris flow active areas are typical ecologically fragile areas. These areas are prone to natural factors (e.g., debris flow and landslide). Moreover, the ecological equilibrium of these areas is vulnerable to social, economic, and technological development activities concerning land cover changes [22]. Longnan City in Gansu Province, China, has been affected by debris flows for a long time; however, it is also a model with mature DFWSL use experience. Agriculture and townships in Longnan City are developed along the Bailongjiang River. The debris flow area in the middle of Bailongjiang River accounts for $52.07 \%$ of the flat area in the valley [55]. The development and use of the debris flow area has initiated positive outcomes with regard to serious water and soil losses and shortage of land resources.

This study analyzed the evolution of DFWSL use and cover changes in Longnan City from 2005 to 2015 and investigated the influence of natural factors (natural disasters) and socioeconomic factors (policies) on the transformation of land use patterns. The objectives were to explore new development paths for the development and use of land resources in mountainous regions and to find new ways to accelerate the transition to sustainable development [56], especially in ecologically fragile areas where soil erosion has taken place. Besides simultaneously addressing poverty alleviation and soil erosion prevention, this study also aimed to solve the problem of dislocation between ecologically sustainable construction and farmers' income through comprehensive management of small basins. This is likely to promote the evolution of a harmonious development zone and a land ecological experimental zone [57]. On one hand, these measures will help control the degree of mountain exploitation; on the other hand, they will improve the efficiency of land use in ecologically fragile areas, optimize the development and management of wasteland, ensure the minimum area of arable land, and finally, achieve sustainable use of land resources in mountainous areas. All these measures can contribute to rural population retention and rural prosperity.

\section{Materials and Methods}

\subsection{Study Area}

Wudu District is located in southeastern Gansu Province, China and is situated along the middle reaches of the Bailongjiang River, a tributary of the Jialing River in the Yangtze River Basin. Its geographical coordinates are $32^{\circ} 47^{\prime} \sim 33^{\circ} 42^{\prime} \mathrm{N}$ and $104^{\circ} 34^{\prime} \sim 105^{\circ} 38^{\prime} \mathrm{E}$ (Figure 2). Wudu District is a debris flow-stricken area. According to incomplete statistics, the district has been affected by debris flow nearly 240 times [58], causing significant casualties and property losses. Field investigations [56] have indicated 172 debris flow gullies in the Zhouqu and Wudu districts along the middle reaches of the Bailongiiang River to form DFWSL areas of various sizes. Eighty-six of these are scattered from the 
Shawan section to the Gushuizi section, with a total acreage of $2550.91 \mathrm{hm}^{2}$. The number of DFWSL areas on the left bank is 52, with an area of $1619 \mathrm{hm}^{2}$; the other 34 have formed on the right bank, covering a total area of $931.91 \mathrm{hm}^{2}$. The largest debris flow accumulation fan in this section is the Gouba fan, with a maximum width of $2.3 \mathrm{~km}$ and a maximum length of $2.4 \mathrm{~km}$, to cover a total area of $3.01 \mathrm{~km}^{2}$. Fifty-nine DFWSLs exist from the Gushuizi section to the Bikou section and cover a total area of $155.99 \mathrm{hm}^{2}$. Of these, 33 DFWSL areas are found on the left bank and 26 on the right back, covering $75.64 \mathrm{hm}^{2}$ and $8.35 \mathrm{hm}^{2}$, respectively. The single largest DFWSL area in this section, the Jugan DFWSL, is about $410 \mathrm{~m}$ wide and $650 \mathrm{~m}$ long, with an area of about $15.89 \mathrm{hm}^{2}$. The smallest, the Yangsiba debris flow land, is $100 \mathrm{~m}$ long, $80 \mathrm{~m}$ wide, and $0.32 \mathrm{hm}^{2}$ in area. According to preliminary data, exploited areas of the Bailongjiang River basin total $2808.2 \mathrm{hm}^{2}$, accounting for $93 \%$ of the flat area.

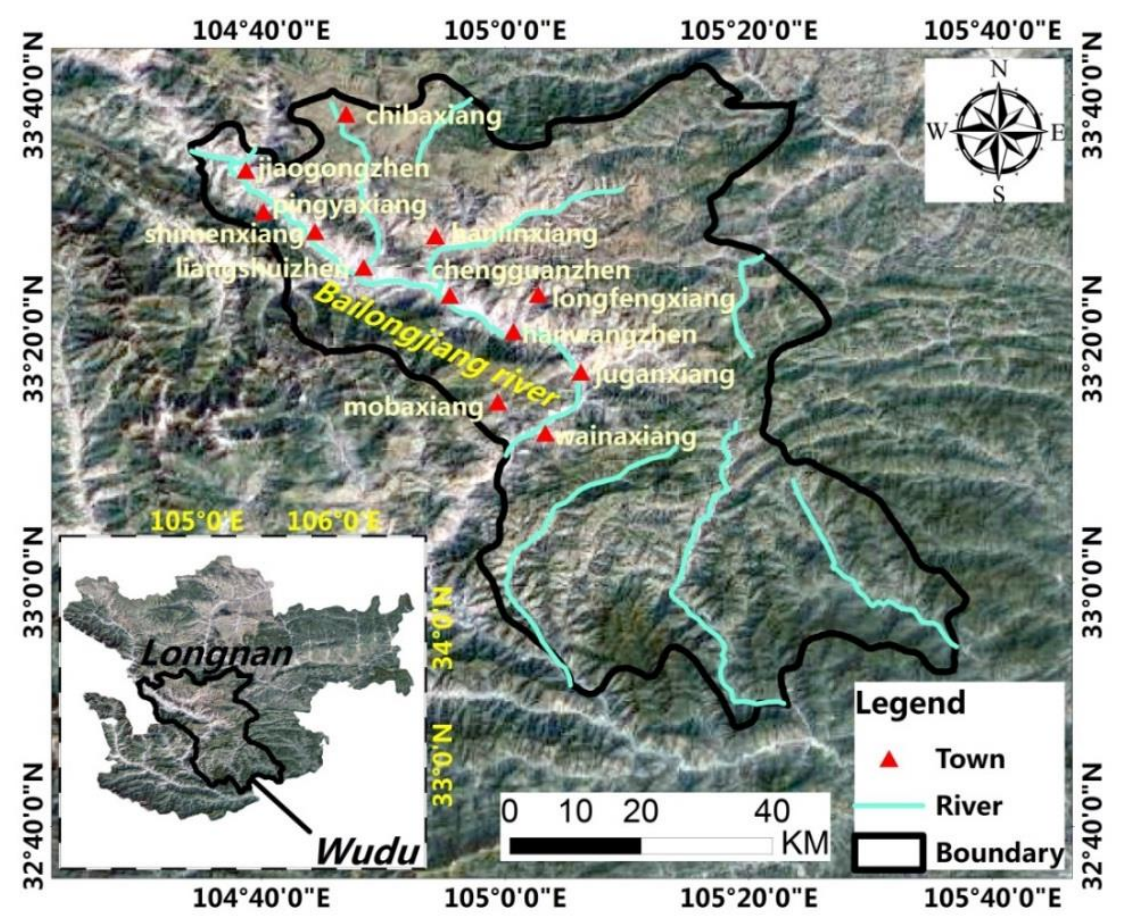

Figure 2. Location of Wudu District.

Cinnamon soil, entisol, loessial soil, and rocky soil (soil classification is based on the World Reference Base) are the four main soil types in Wudu District. Cinnamon soil and entisol are mainly distributed in valley terraces with low altitudes. The two soils are high yield soil types because of moderate texture and high potential fertility. Grain crops include corn, wheat, potato and rapeseed, while economic crops include vegetables, watermelons, olives, Chinese prickly ash, and grapes. The local economy of Wudu District mainly thrives on the sale of crops such as olives, peppers, grapes, potatoes, and canola. According to a year-long field investigation, the olive yield is about $2250 \mathrm{~kg}$ per ha and the purchase price is about $10 \mathrm{CNY} / \mathrm{kg}$. Thus, income is about CNY 22,500/ha. The Chinese prickly ash yield is about $750 \mathrm{~kg}$ per ha with a purchase price of about $100 \mathrm{yuan} / \mathrm{kg}$, providing an income about CNY 75,000 per ha. The rapeseed yield is about $2250 \sim 3000 \mathrm{~kg}$ per ha and its purchase price is about CNY $4 / \mathrm{kg}$, yielding an income per ha of about CNY 9000-12,000. The potato yield is about $600 \mathrm{~kg}$ per ha, its purchase price is about CNY 2/ $\mathrm{kg}$, and the income per ha is about CNY 1200 .

At present, apart from farmland and forests, the DFWSL areas in Wudu District have also been transformed into construction land and township development sites where site conditions are appropriate (Figure 3). 


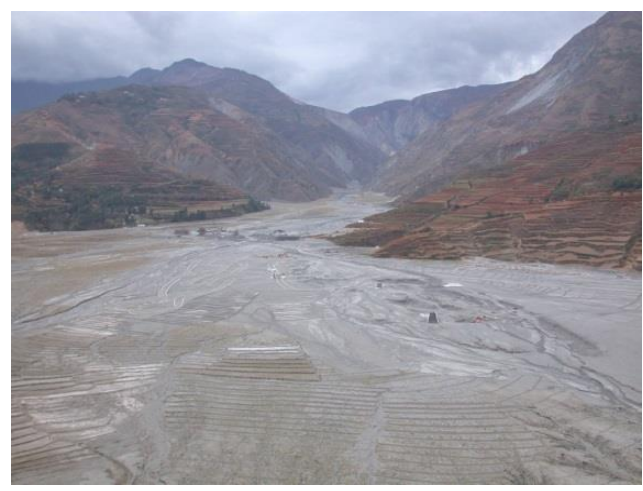

(a)

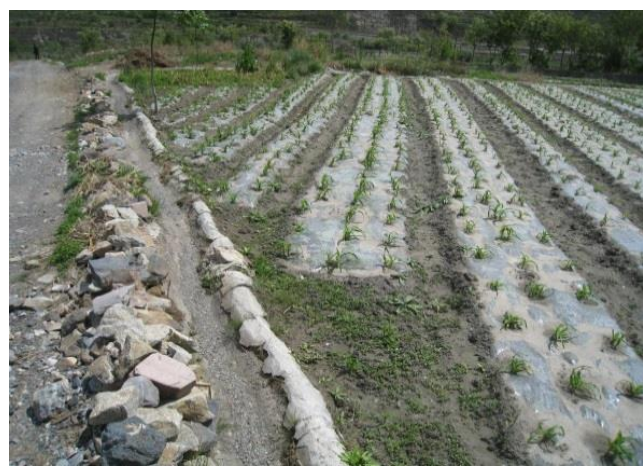

(c)

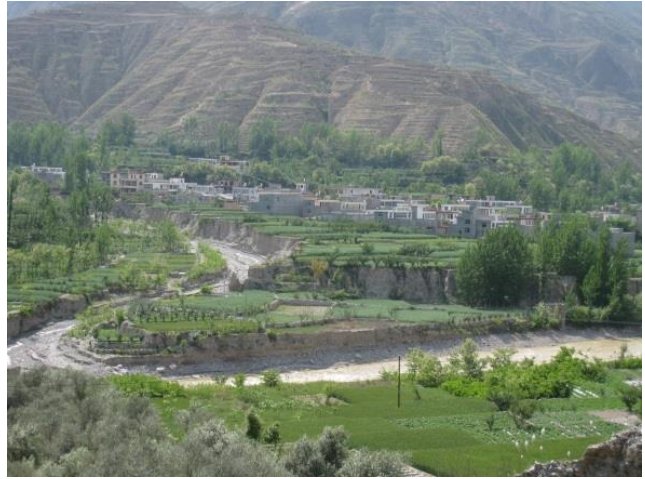

(e)

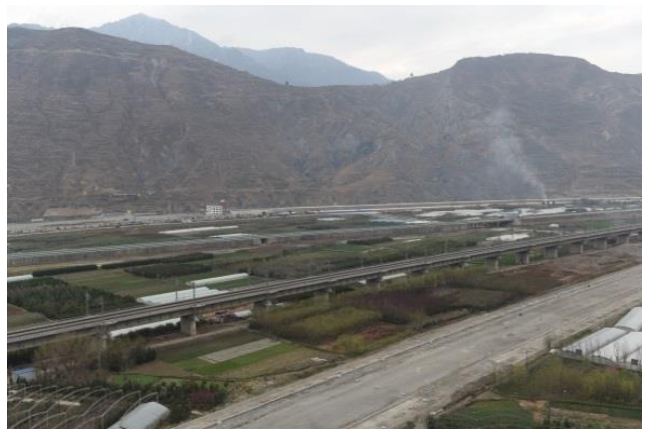

(g)

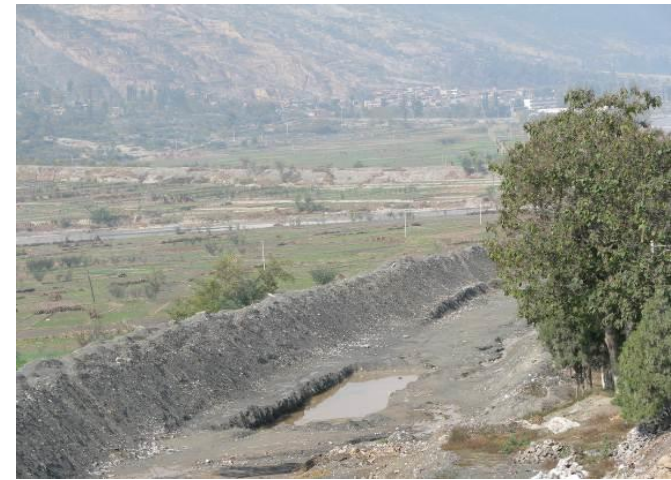

(b)

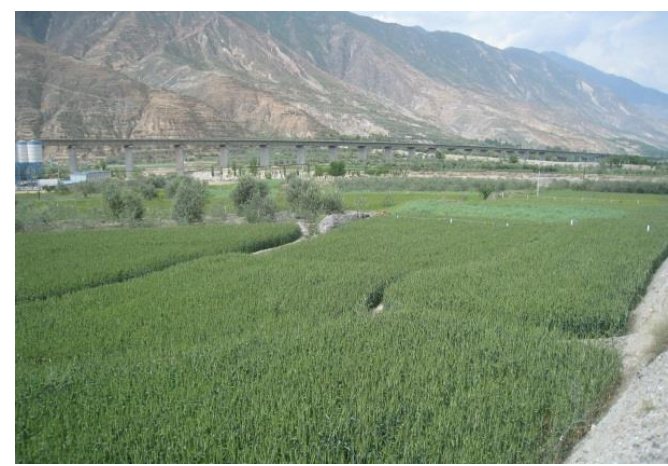

(d)

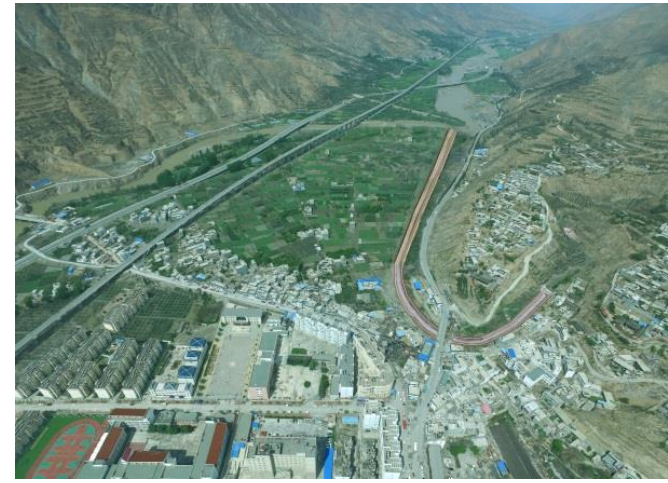

(f)

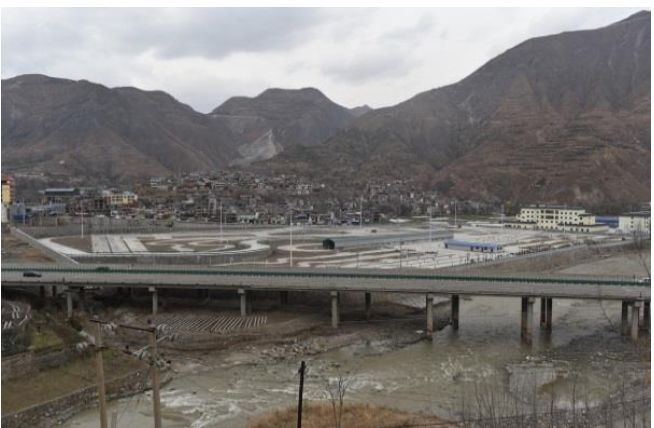

(h)

Figure 3. Different types of debris flow waste-shoal lands use in Wudu District: (a) Primitive debris flow waste-shoal land; (b) overgrown with weeds; (c,d) developed into cultivated land; (e,f) villages or towns; and, (g,h) traffic network construction. 


\subsection{Data Collection and Methodology}

Satellite remote sensing has been proven to be a suitable approach for detecting and monitoring land use transformations [59]. This study used land use raster data with a spatial resolution of $1 \mathrm{~km}$ to study land use changes in the Wudu District in 2005, 2010, and 2015 (Tables 1 and 2, Figure 3). A $2.15 \mathrm{~m}$ (no deviation) resolution image of Chenjiaba village in 2014, and again 2017, was obtained from Google Maps. The images were digitized using ArcGIS 9.3. The features in the area were divided into four categories by visual interpretation: Cultivated land, woodland, water, and construction land (Figure 4). Furthermore, the land area was constructed as a land use transfer matrix (Tables 3-5) using the method of Braimoh [60]. Additionally, the current situation and changes of various land use types were quantitatively analyzed. To quantitatively characterize the rate of land use change in the study area within a given time interval, the dynamic degree of land use was used [21]. It is described as follows:

$$
K=\frac{U_{2}-U_{1}}{U_{1}} \times \frac{1}{T} \times 100 \%
$$

where $K$ is the dynamic degree of land use; $U_{1}$ and $U_{2}$ are the area of a land type at the beginning and the end of a period, respectively; and $T$ is time interval (years). This equation can be used to analyze and compare the rates of change among different land use types in the study area.

\section{Results}

\subsection{Temporal and Spatial Patterns of Land Use Transformation in DFWSL}

\subsubsection{Overall Conditions of Land Use Transformation in Wudu District}

The distribution of land use types in Wudu District, according to the classified remote sensing images is shown in Figure 4; the ratios are shown in Table 1. Wudu District has developed along the Bailongjiang River and belongs to the mountain-valley land type. The land use pattern in mountainous areas is limited by site conditions and the climate. The middle and high mountain areas are dominated by grasslands and woodlands, which accounted for about $52 \%$ and $22 \%$ of the total area, respectively. The lowland flat areas, mainly constituted cultivated land and accounted for about $24 \%$ of the total area (Table 1). The transformation in land use types from 2005 to 2015 (Table 2) suggests that the area of cultivated land has decreased (a decrease of $36.5395 \mathrm{~km}^{2}$ from 2005 to 2015) and transformation to other land types has largely shown an increasing trend.

Table 1. Land use in Wudu District in 2005, 2010, and 2015.

\begin{tabular}{ccccccc}
\hline \multirow{2}{*}{ Type } & \multicolumn{2}{c}{$\mathbf{2 0 0 5}$} & \multicolumn{2}{c}{$\mathbf{2 0 1 0}$} & \multicolumn{2}{c}{$\mathbf{2 0 1 5}$} \\
\cline { 2 - 6 } & Acreage $\mathbf{( k m}^{\mathbf{2}} \mathbf{)}$ & Ratio $\mathbf{( \% )}$ & Acreage $\left.\mathbf{( k m}^{\mathbf{2}}\right)$ & Ratio $\mathbf{( \% )}$ & Acreage $\left.\mathbf{( k m}^{\mathbf{2}}\right)$ & Ratio $\mathbf{( \% )}$ \\
\hline Grassland & 2388.8834 & 0.5218 & 2395.0128 & 0.5232 & 2406.3738 & 0.5257 \\
Cultivated land & 1106.5583 & 0.2417 & 1098.9520 & 0.2400 & 1070.0188 & 0.2337 \\
Woodland & 1018.3564 & 0.2223 & 1019.4410 & 0.2225 & 1020.5569 & 0.2228 \\
Water & 15.4206 & 0.0034 & 15.7698 & 0.0034 & 16.4690 & 0.0036 \\
Construction land & 40.1770 & 0.0088 & 40.2202 & 0.0088 & 54.0303 & 0.0118 \\
Unused land & 8.4034 & 0.0018 & 8.4034 & 0.0018 & 10.3504 & 0.0023 \\
\hline
\end{tabular}

Table 2. Area statistics on land use changes in Wudu District $\left(\mathrm{km}^{2}\right)$.

\begin{tabular}{ccccccc}
\hline Type & $\mathbf{2 0 0 5}$ & $\mathbf{2 0 1 0}$ & $\mathbf{2 0 1 5}$ & $\mathbf{2 0 0 5 - 2 0 1 0}$ & $\mathbf{2 0 1 0 - 2 0 1 5}$ & $\mathbf{2 0 0 5 - 2 0 1 5}$ \\
\hline Grassland & 2388.8834 & 2395.0128 & 2406.3738 & 6.1294 & 11.361 & 17.4904 \\
Cultivated land & 1106.5583 & 1098.952 & 1070.0188 & -7.6063 & -28.9332 & -36.5395 \\
Woodland & 1018.3564 & 1019.441 & 1020.5569 & 1.0846 & 1.1159 & 2.2005 \\
Water & 15.4206 & 15.7698 & 16.469 & 0.3492 & 0.6992 & 1.0484 \\
Construction land & 40.177 & 40.2202 & 54.0303 & 0.0432 & 13.8101 & 13.8533 \\
Unused land & 8.4034 & 8.4034 & 10.3504 & 0 & 1.947 & 1.947 \\
\hline
\end{tabular}


In particular, after 2010, the growth rate of construction land was at its highest, showing an increase of $13.8533 \mathrm{~km}^{2}$ from2005 to 2015 to account for $25.64 \%$ of the total construction land. The growth rate of construction land from 2010 to 2015 was $6.87 \%$, while the growth rate from 2005 to 2010 was only $0.11 \%$. This rate brought about an increase in the area of construction land, which can also be verified from the number of patches indicated by red circles in Figure 4.

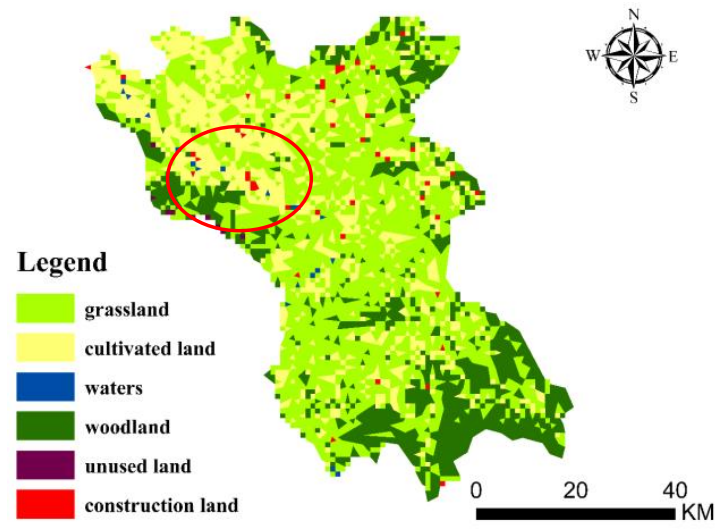

(a) 2005

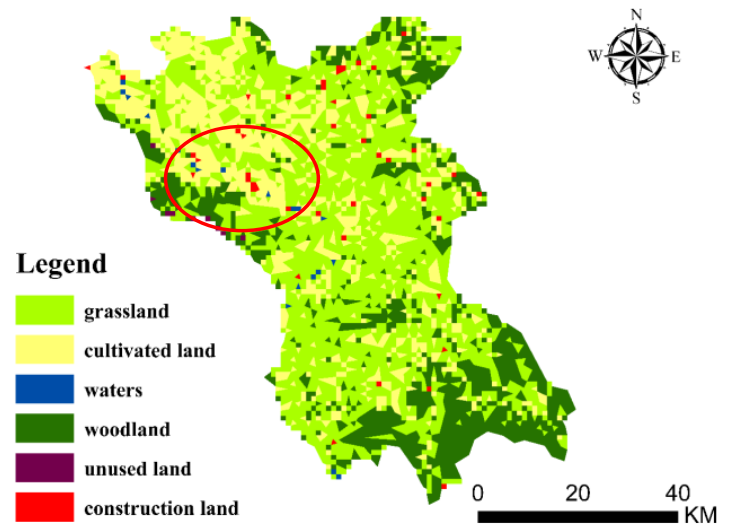

(b) 2010

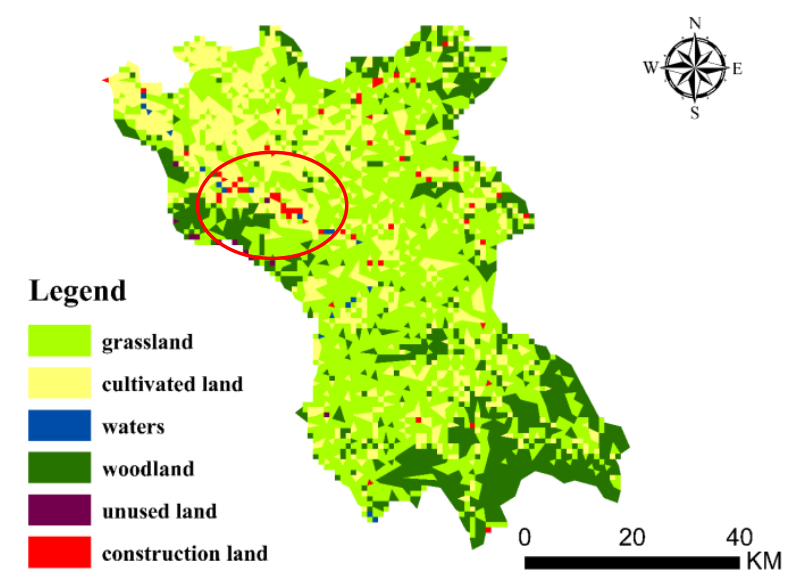

(c) 2015

Figure 4. Distribution of land use types in Wudu District in (a) 2005, (b) 2010, and (c) 2015.

To illustrate the mutual transformation of land types on DFWSL and clear land transformation trends, and analyze the spatial-temporal change patterns of DFWSL [61], ArcGIS was used to calculate matrices of land use transformation from 2005 to 2010 and from 2010 to 2015 (Tables 3 and 4).

As indicated in Table 3, the overall change from 2005 to 2010 was slight and represented by transfer-ins and transfer-outs of cultivated land, with transfer-outs outnumbering transfer-ins. Nearly $10.4233 \mathrm{~km}^{2}$ of the cultivated land was converted into grassland, $1.2984 \mathrm{~km}^{2}$ into woodland, and a very small part $\left(0.3791 \mathrm{~km}^{2}\right)$ was converted into water area, totaling $12.1001 \mathrm{~km}^{2}$. The transfer-ins were mainly from grasslands, which accounted for $4.2508 \mathrm{~km}^{2}$. The remaining areas were converted from woodland and water, which accounted for $0.2137 \mathrm{~km}^{2}$ and $0.0299 \mathrm{~km}^{2}$, respectively. As a result of the transformation progress, the cultivated land outflowed to other land types with a net outflow of $7.6063 \mathrm{~km}^{2}$. 
Table 3. Land uses transformation matrix for Wudu District from 2005 to $2010\left(\mathrm{~km}^{2}\right)$.

\begin{tabular}{cccccccc}
\hline Type & Grassland & Cultivated Land & Woodland & Water & Construction Land & Unused Land & $\mathbf{2 0 0 5}$ \\
\hline Grassland & 2384.4447 & 4.2508 & 0 & 0 & 0.188 & 0 & 2388.8834 \\
Cultivated land & 10.4233 & 1094.4575 & 1.2984 & 0.3791 & 0 & 0 & 1106.5583 \\
Woodland & 0 & 0.2137 & 1018.1427 & 0 & 0 & 0 & 1018.3564 \\
Water & 0 & 0.0299 & 0 & 15.3907 & 0 & 0 & 15.4206 \\
Construction land & 0.1449 & 0 & 0 & 0 & 40.0322 & 0 & 40.177 \\
Unused land & 0 & 0 & 0 & 0 & 0 & 8.4034 & 8.4034 \\
2010 & 2395.0128 & 1098.9520 & 1019.4410 & 15.7698 & 40.2202 & 8.4034 & 4577.7992 \\
\hline
\end{tabular}

A comparison of results from 2010 to 2015 (Table 4) with those from 2005 to 2010 indicates that although the decrease of arable land was still the prevailing trend, an increase in either the total quantity or transformation rate was more prominent. Although the outflow of arable land was still dominated by grassland $\left(15.4292 \mathrm{~km}^{2}\right)$, the outflow to woodland, water, and unused land increased exponentially from 2005 to 2010 . Additionally, the area of arable land transforming to construction land significantly increased. It surged from near zero in 2010 to $13.998 \mathrm{~km}^{2}$ in 2015 and the increased acreage accounted for $34.80 \%$ of the acreage of construction land in 2010 .

Table 4. Land use transformation matrix for Wudu District from 2010 to $2015\left(\mathrm{~km}^{2}\right)$.

\begin{tabular}{cccccccc}
\hline Type & Grassland & Cultivated Land & Woodland & Water & Construction Land & Unused Land & $\mathbf{2 0 1 0}$ \\
\hline Grassland & 2389.1242 & 3.8906 & 0.8162 & 0 & 0.2071 & 0.9747 & 2395.0128 \\
Cultivated land & 15.4292 & 1065.2159 & 2.3967 & 0.9400 & 13.9980 & 0.9722 & 1098.9520 \\
Woodland & 1.8204 & 0.2467 & 1017.3440 & 0 & 0.0299 & 0 & 1019.4410 \\
Water & 0 & 0.1809 & 0 & 15.5290 & 0.0598 & 0 & 15.7698 \\
Construction land & 0 & 0.4847 & 0 & 0 & 39.7355 & 0 & 40.2202 \\
Unused land & 0 & 0 & 0 & 0 & 0 & 8.4034 & 8.4034 \\
2015 & 2406.3738 & 1070.0188 & 1020.5569 & 16.4690 & 54.0303 & 10.3503 & 4577.7992 \\
\hline
\end{tabular}

\subsubsection{Land Use and Transformation in a Typical DFWSL}

To illustrate the land use transformation of DFWSL, this study narrowed its study scope by selecting Chenjiaba village as a research site. Chenjiaba village is completely constructed on converted DFWSL (Figure 5). Land use maps for 2014 and 2017 were selected, together with Google images (Figure 6); an analysis was conducted in terms of land use and transformation. As shown in Figure 5, in 2014 the DFWSL in the village was mainly developed into cultivated land and a small area of construction land. However, in 2017, most of the cultivated land had outflowed and transformed into construction land, which significantly increased the acreage of construction land. Figure 5 shows detailed land use and transformation trends in 2014 (a) and 2017 (b).

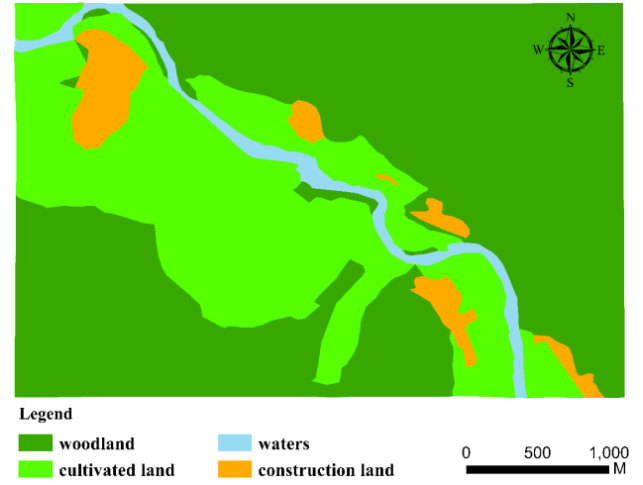

(a)

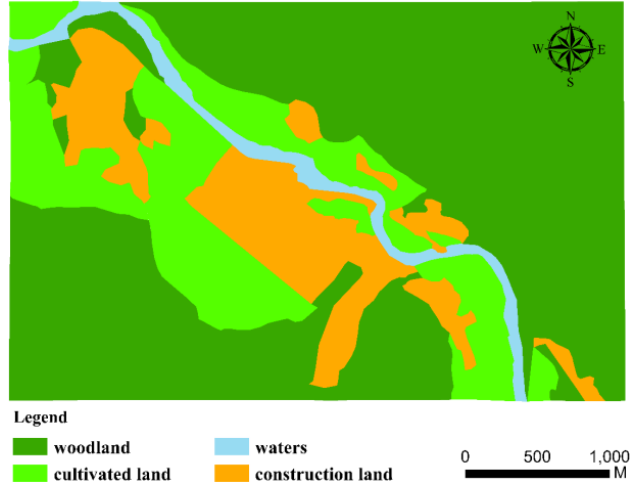

(b)

Figure 5. Land use and transformation maps of Chenjiaba village: (a) Status of land use type in 2014; (b) status of land use type in 2017. 


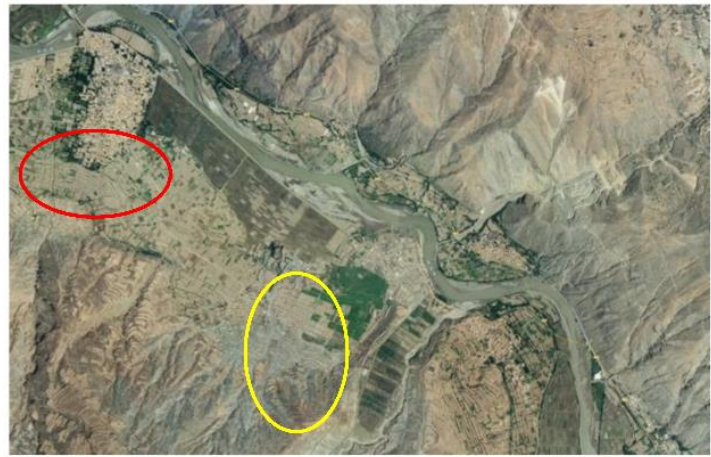

(a)

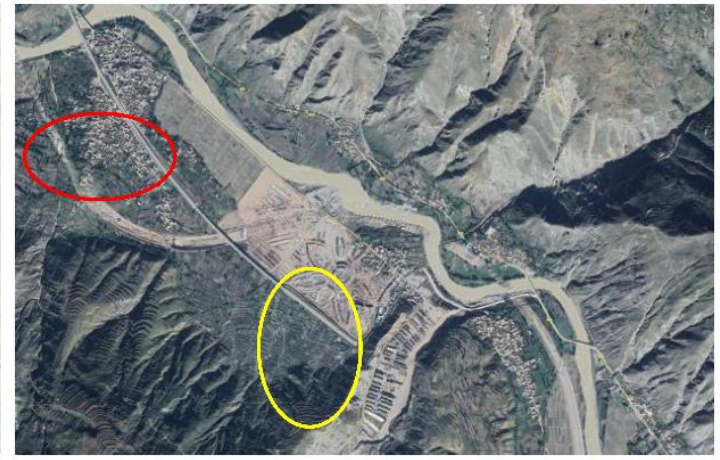

(b)

Figure 6. Google images of land use transformation of DFWSL in Chenjiaba village: (a) Status of land use in 2014; (b) status of land use in 2017. Red circles represent arable land in 2014, most of which became construction land (residential area) in 2017; yellow circles show woodland (olive-planting sites) in 2014, which was converted into construction land in 2017.

The DFWSL developed along the riverside showed features of flat terrain, abundant water and heat, and easy access to traffic. Therefore, the use of this land is goal-oriented and well targeted. Woodlands were transformed into artificial forests for growing economic crops, such as olives; and some were also converted into arable land. Before 2014, woodland and arable land accounted for $92.06 \%$ of the land in the village. In 2017, the woodland remained largely unchanged. However, almost a third of the arable land resources outflowed and transformed into construction land, which tripled the percentage of construction land from $4.6 \%$ to $14.59 \%$ (Table 5). As a representative of the DFWSL use and transformation model of the Bailongiiang River Basin, the pattern of land transformation in Chenjiaba village reflects the trend of conversion of land use type. Most of the arable land in Wudu District was transformed from DFWSL along the river. Therefore, the increased construction land was transformed from DFWSL in the low-relief terrain.

Table 5. Land use and transformation matrix of DFWSL in Chenjiaba village, Wudu District from 2014 to $2017\left(\mathrm{~km}^{2}\right)$.

\begin{tabular}{cccccc}
\hline Type & Woodland & Cultivated Land & Waters & Construction Land & $\mathbf{2 0 1 4}$ \\
\hline Woodland & 6.8687 & 0.04947 & 0.03942 & 0.06428 & 7.0219 \\
Cultivated land & 0.2928 & 2.3796 & 0 & 1.0981 & 3.7704 \\
Waters & 0 & 0.0066 & 0.3776 & 0 & 0.3842 \\
Construction land & 0 & 0 & 0 & 0.5440 & 0.5440 \\
2017 & 7.1615 & 2.4356 & 0.4170 & 1.7063 & 11.7205 \\
\hline
\end{tabular}

\subsection{Driving Forces of Land Use and Land Changes of DFWSL}

Traditional geography focuses on morphology and patterns and pays little attention to underlying processes, especially the influences of patterns on the process. Therefore, this study revealed the underlying factors driving DFWSL use and transformation through change patterns.

\subsubsection{Natural Driving Forces}

DFWSL areas are located in the active debris flow area. They are extremely sensitive to vulnerable habitats and easily prone to natural disasters. Therefore, land use and changes of DFWSL in Wudu District resulted from debris flows and earthquakes. The annual precipitation in Wudu District is relatively large and the temporal and spatial distributions are uneven. Precipitation is largely in the form of heavy and torrential rains that often occur from May to September. The rainfall during this period accounts for $79.2 \%$ of the whole year. Since 1951, heavy rains with daily precipitation of over 25 
$\mathrm{mm}$ has occurred on average 2.7 times per year; daily precipitation of over $50 \mathrm{~mm}$ has occurred once per year. In the past 20 years, the number of heavy and torrential rain events has increased significantly; for example, extremely heavy rainstorm events occur on average 4.3 times a year. Each event exceeds the criticality for debris flows. According to data from the meteorological department, in the event of torrential rains, intensity exceeds $8 \mathrm{~mm}$ within $10 \mathrm{~min}$.

According to historical records, in Houba village, Wudu District, large-scale debris flows have occurred five times, in 1956, 1967, 1984, 1998 [62], and 2005. Moreover, on 21 June 2006, the village was struck by a 5.0 magnitude earthquake with an epicenter at $105^{\circ} \mathrm{E}$, and $33.1^{\circ} \mathrm{N}$. This earthquake adversely impacted the Niwangou gully and banks. The village was also affected by the Wenchuan earthquake which occurred in Sichuan on 12 May, 2008. Parts of Niwangou gully collapsed and mudslides blocked the gully while cracks were widened. The most serious blockages happened in the middle and lower reaches of the Niwangou gully, where slumps from both sides of the gully bank silted up the trench. The volume of debris flow from solid loose material was about $20 \times 104 \mathrm{~m}^{3}$.

Houba village is built on the DFWSL and contains 520 households with a total of 2600 residents. Five large-scale mudslides have occurred (i.e., those in 1956, 1967, 1984, 1998, and 2005); these destroyed more than 50 private residences and over 150 acres of farmland, burying 15 livestock, damaging a $200 \mathrm{~m}$ streth of long state highway, and resulting in direct economic losses of more than CNY 4.20 million. The damaged houses could not be reconstructed on the original sites and the buried farmlands were unsuitable for cultivation over a short period of time. For these reasons, these lands were developed into woodland, which increased water and soil conservation. In summary, frequent natural disasters have caused uncertainties in the use of DFWSL.

The frequent occurrence of debris flow hazards in the Wudu District is closely related to the condition of soil and vegetation in the area. The middle-high mountains mainly consist of loessial and rocky soils. They belong to entisol, with a large quantity of gravel, and their structure is loose. There is almost no bedrock distribution, suggesting that the soil is unstable and highly erodible. In addition, the vegetation in the area is unevenly distributed, with forests as the main type. The vegetation coverage at an altitude of $1800 \mathrm{~m}$ is less than $50 \%$. The vegetation at $1400 \mathrm{~m}$ altitude comprises various grasses with a coverage rate of less than $20 \%$. The vegetation coverage in the valleys on both sides of the mainstream of the Bailongjiang River (debris flow beach concentrated area) is low (NDVI $<0.3$ ). Within this range, the capacity of the vegetation to retain water and soil is poor; therefore, it is prone to mudslides. About $65.53 \%$ of the total area is a high-risk mudslide-intensive area [63]. In summary, the harsh environment of the underlying surface cannot withstand natural disasters; this results in frequent changes in land use in the debris flow area.

Land use in the debris flow area, especially the development and use of DFWSL, is initially cultivated land, woodlands, or construction land and is largely dependent on the presence of frequent and catastrophic mudslides. If land is relatively stable with good site conditions, it will be developed into construction or arable land; otherwise, it will be converted into woodland in order to preserve water and soil. This is very different from the choice of land use types in ecologically non-vulnerable areas. In general, the development of ecologically non-vulnerable areas assumes that the impacts of natural disasters are non-existent or negligible because the priority is to balance economic benefits and ecological conservation. Therefore, in the debris flow active area, land use and transformation are strongly affected by natural factors, which significantly impact land planning, resource management, and risk control.

\subsubsection{Characteristics of Land Transformation and Demographic Migration}

According to the Regional Statistical Yearbook (Wudu district), the population was 530,000 in 2005, 544,480 in 2010, and 592,000 in 2015 indicating a growing trend, especially from 2010 to 2015. Along with population growth, land use and transformation also changed across the same period [64]. From 2010 to 2015, woodland and construction land noticeably increased while cultivated land decreased. This change was brought about by transformation of land use of the DFWSL along 
the river. Only a small region in the middle-high mountainous area was affected by mudslides; because the underlying surface in this area is seldom affected, there remain largely unchanged land types. Moreover, owing to different topographies, construction land and cultivated land underwent few changes.

To understand the correlation between population growth and the use and transformation of DFWSL, the population of Chenjiaba village (a village completely built on DFWSL in Wudu District) from 2005 to 2015 was assessed. The population was close to 300 in 2005, and had increased to 560 in 2010, and 1156 in 2015. Land use and transformation in Chenjiaba village were characterized by the outflow of cultivated land to construction land (Figures 5 and 6). The relationship between population and land use and transformation is as follows: A negative correlation between population growth and the reduction of arable land was observed while the correlation between population growth and an increase in construction land was positive. The growth of the population in Chenjiaba village was due to inward migration of people from Pingya village, which is located in the middle-high mountains. Therefore, the land originally used for residential areas was converted to forests, grasslands or cultivated land in Pingya village. Consequently, land transformation conditions in Pingya village were the opposite to those in Chenjiaba village.

Therefore, the relationship between land transformation and population change results from the impact of population distribution on land use. Population distribution and land use type changes are also affected by scale and range. At large scales, they may not be related while at small and medium scales, local population changes will lead to distinctive changes in land use.

\subsubsection{Changes in Land Use Policies and Strategies}

Anthropogenic activity and regional development profoundly influence ecosystems and land use patterns [65]. According to the Regional Land Resources Bulletin (Wudu district), since the implementation of the policy of returning farmland to forests in 1999, China has attached great importance to the recovery of forests and, in particular, the recovery of ecologically fragile areas. The forest areas in Wudu District increased from 2005 to 2015. Additionally, China implemented the policy of "direct subsidies to grain producers" in 2004, canceled agricultural taxes in 2005, issued farmland protection funds in 2009 , and has gradually provided skills training to rural laborers. The implementation of these policies has promoted the development and use of DFWSL to turn unavailable land into useful land resources. At present, in response to the initiative of rural revitalization [66] and the country's poverty alleviation policies, the development and use of DFWSL is approaching the goal of building a nation that boasts "productive and compact producing spaces, comfortable and cozy living spaces, and picturesque ecological scenes" [67].

The period from 2016 to 2020 is a decisive stage for China with regard to building a moderately prosperous society. Poverty alleviation has been the focus of rural construction work in recent years. Although the amount of traditional arable land continues to decrease, recent years have witnessed the effective adjustment of agricultural structure and the industrial layout structure has begun to take shape. In particular, the adoption of intensive and efficient land use patterns for the cultivation of pepper, walnuts, olives, vegetables, and Chinese herbal medicines have been explored and modified through greenhouse agriculture and multi-dimensional eco-agriculture to significantly increase the income of farmers. In 2010, the household operating income of farmers in Wudu District reached CNY 1250 and reflected an increase of CNY 502 over that in 2005 (CNY 748). This is an average annual increase of $8.03 \%$ and accounts for $56.43 \%$ of total net income. Moreover, urbanization also provides a broader perspective for people to develop secondary and tertiary industries within their households, especially in the catering, transportation, traffic, and construction industries, all of which have not only provided employment for farmers but also increased farmer incomes. For example, the Lanyu railway and the Lanhai expressway have facilitated traffic in Wudu District. Moreover, the Hanwang $330 \mathrm{KV}$ transformer substation has been completed and put into production, stimulating investment in exponential growth and subsequent industry development. At the same time, this substation also 
created employment and provided opportunities for increasing farmer incomes. The development of catering and real estate industries and increased traffic require more land which is often categorized as land for construction. Therefore, the acreage of construction land increased dramatically after 2010, and arable land decreased rapidly, especially in development-oriented areas (for example, the land near Chenjiaba, as shown in Figures 5 and 6). The increased land for construction also includes space for various types of infrastructure such as drainage systems and blockage measures.

In summary, in the area where mudslides occurred, the country's policies or strategies in different periods influenced the diversity of certain types of land use; however, the complete transformation of one land type to another could not be determined. For any country or region, land use should comply with the overall standards of being "safe, harmonious, open, coordinated, competitive, sustainable, and beautiful". This highlights the difference between the influence of policy or strategy and natural factors on land use and transformation. In general, natural driving forces can promote complete transformation of land use types, while policy or strategy does not play a decisive role in the transformation.

\section{Discussion}

\subsection{A Comparison between Our Study and Other Similar Area}

The Pokhara valley is an intermountain fluvial basin occupying the midsection of the Seti River in the Lesser Himalayas of Nepal. It holds a large volume of layered clastic deposits of gravel, silt and clay of Quaternary age [68,69]. This area, like Wudu, is located in an ecologically fragile area and is subject to frequent landslides and debris flow. Both these areas are sensitive to natural factors and human influence. The land cover changes are characterized by increses in construction land. In addition, land use structure is becoming increasingly diverse, expanding to include not only construction and forest land, but also water areas and grassland. At present, much of the city's rapid growth in population has been accommodated in temporary settlements that are at high risk of environmental impairments and hazards in Pokhara [70]. However, Wudu district has adopted a more rational settlement for population growth for example, moving people away from danger zones to a safe area (Pingya village to Chenjiaba village, as shown in our study). Furthermore, in Wudu district, in addition to land use and land use changes, emphasis is also placed on the measures to conserve soil and water and ecological protection (Figure 7), such as cultivating vegetation for slope protection (Figure 7a,b), and geotechnical engineering (Figure $7 \mathrm{c}, \mathrm{d}$ ).

In recent years, marginal lands have attracted widespread concern due to their potential for exploitation [71,72]. Caserta [73] highlighted that this is likely because many abandoned regions have latent resources of water, energy, and vegetation (e.g., commercial agriculture) which, if properly exploited, could lead to a flourishing modern rural system. It is worth mentioning that the Wudu district pays more attention to maximizing the efficiency of land resources use. Debris flow waste-shoal lands are developed into available land without disrupting the natural environment. While the objectives and ultimate aim of reclamation may differ in the face of individual needs and natural conditions, the essential ideas remain the same: Take ecological restoration and construction as the main lines, pursue the maximization of economic and social benefits from land and achieve sustainable development. Hence, although Wudu is in the debris flow area and experiences fast land use transformation, the risks from natural disasters are also accounted for in the form of corresponding prevention and control measures. 


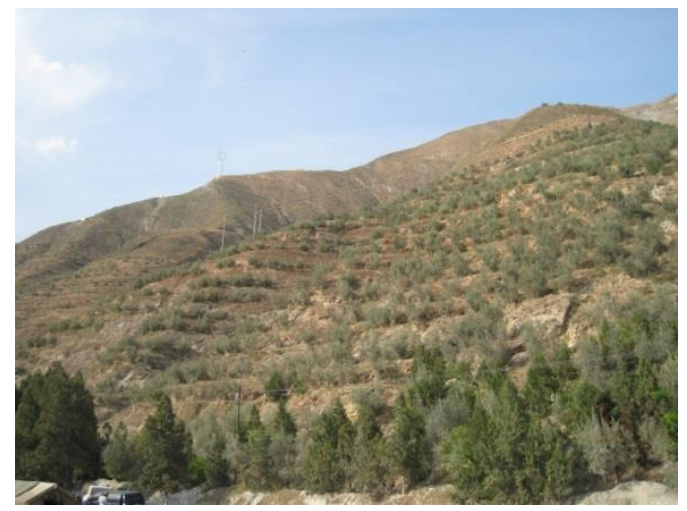

(a)

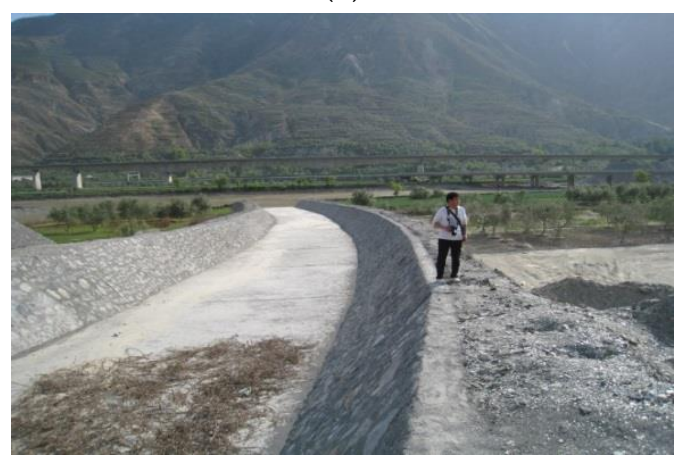

(c)

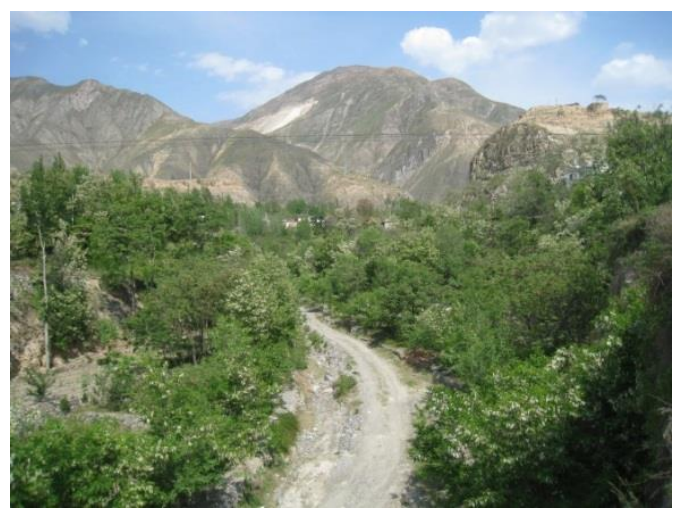

(e)

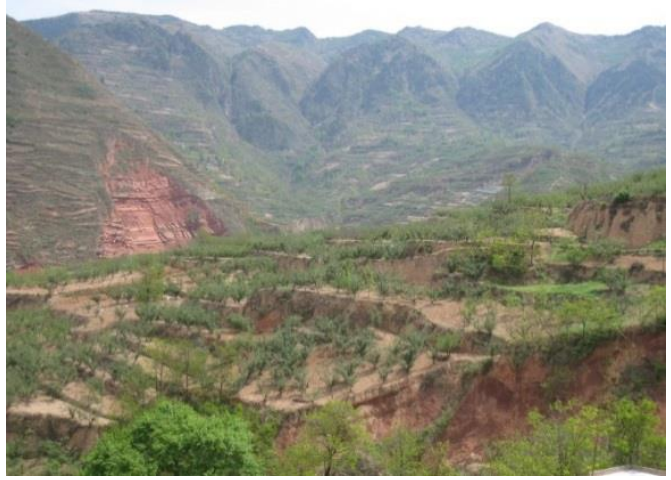

(b)

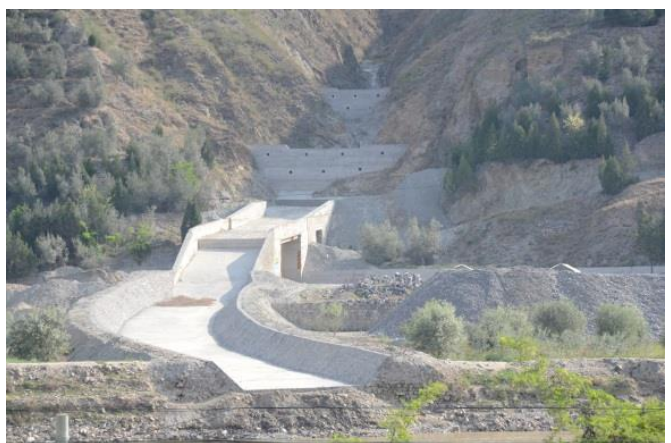

(d)

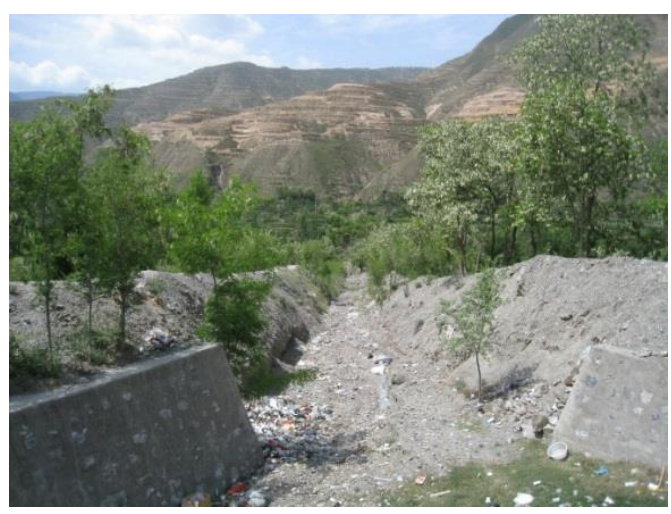

$(\mathbf{f})$

Figure 7. Various measures for ecological preservation: $(\mathbf{a}, \mathbf{b})$ Slope ecological protection measures; $(\mathbf{c}, \mathbf{d})$ drainage groove with check dam; $(\mathbf{e}, \mathbf{f})$ ecological engineering protection in gully.

\subsection{Development Mode Based on Local Conditions}

Moving out of environmentally fragile areas where the environment is harsh and disasters occur frequently is a common sentiment. China is a mountainous country with a large population. The mountainous area accounts for two-thirds of the country's total land and population in these areas exceeds 1.3 billion. Since abandoning these places is unlikely, it is beneficial to take advantage of unique mountainous resources. Although debris flows cause significant damage and losses to the natural environment and humans alike, fans shaped by debris flows are advantageous for human development. At present, there are two types of development models worth recommending: Greenhouse agriculture and multi-dimensional eco-agriculture.

Considering the climate of Wudu District and its site conditions, efficient multi-dimensional eco-agriculture has resulted in intercropping of olives, grapes, walnuts, and pasture to utilize different 
levels of photothermal resources. It has also equipped the region with supporting facilities such as reservoirs, irrigation systems, pig houses, chicken houses, and biogas digesters. Forage is used as feed for chickens, pigs, and fish; the manure of livestock, branches and leaves of walnuts and grapes, and branches of crops can be added to biogas digesters for fermentation; the biogas produced can be used as energy and the remaining waste can be used as fertilizer; the deposits of fish ponds can be used as fertilizer for plant and crops; and the flowers of walnut and grape crops can be used for honey-making during the flowering period (Figure 8). This model, through the recycling of materials and energy flows, forms a number of intertwined industrial chains and organically links the biological environment within the multi-dimensional agricultural system. It is also likely to promote agricultural tourism such as flower viewing in spring and fruit gathering in autumn. Certain locations may also have the potential to develop rural tourism and operate farm stays. Booming rural tourism can increase consumption of green foods and encourage more farmers to embrace three-dimensional agriculture, and finally, build a desirable development situation. Primary industry boosts tertiary industry, which in return can promote the development of agriculture.

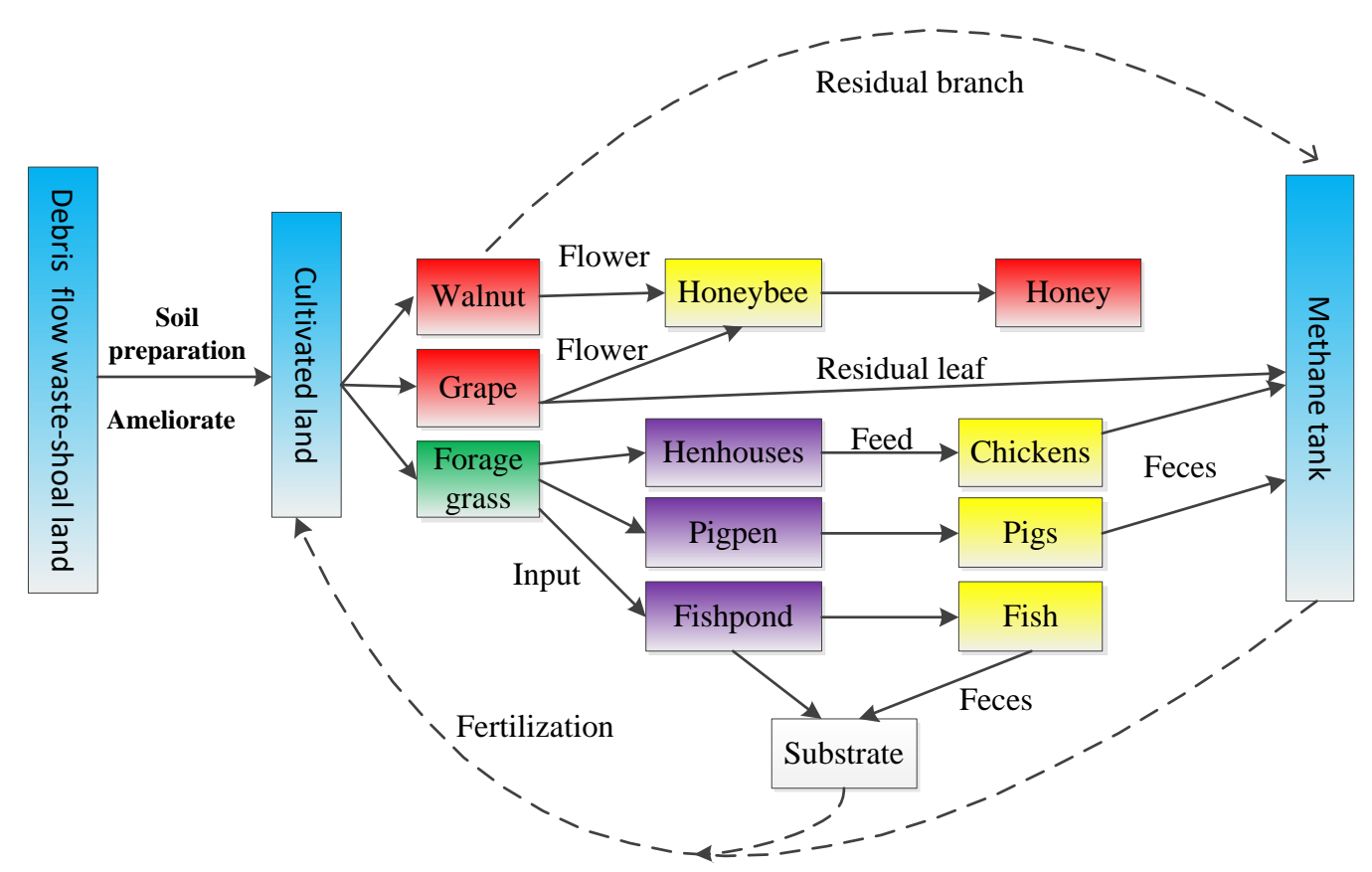

Figure 8. Operational route of multi-dimensional agricultural mode of DFWSL: Recycling of materials and energy flows.

Greenhouse agriculture adopts precise operating and large-scale planting methods. It helps utilize the flat terrain and sufficient water sources to plant non-seasonal fruits and vegetables (Figure 9). Wudu's greenhouse vegetables adjust to market demand and farmers mainly plant white leaf mustard, lettuce, and strawberries. A $2 \mathrm{hm}^{2}$ area of land in the Liangshui town of Wudu District has an annual production value of CNY 450,000 per ha. It not only provides employment for local residents, but also increases their income by CNY 20,000-30,000 per year. At the same time, greenhouse agriculture is pollution-free (as it replaces chemical fertilizers with soybeans, which are highly nutritious), and high-tech; for example, using plant sterilization technology such as the garlic bactericidal method and the use of biological insecticides (introducing Neoseiulus californicus (Acari: Phytoseiidae) to get rid of red spiders in fruit sheds). Such measures have greatly reduced environmental pollution and improved the taste and safety of vegetables and fruits. Therefore, the two types of development models are worth promoting and developing. 


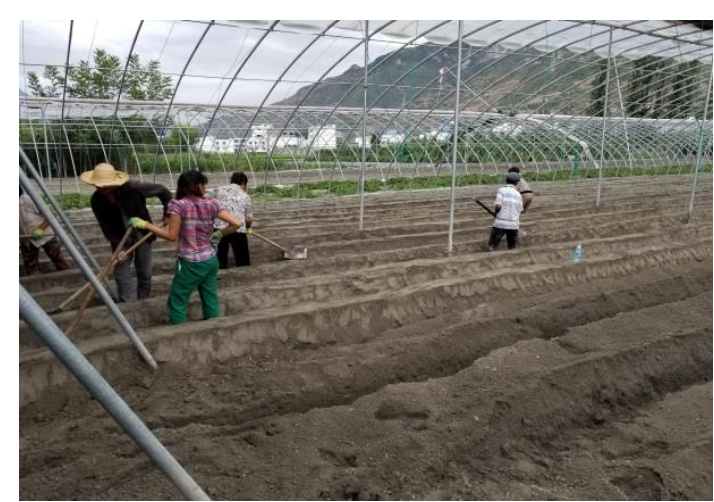

(c)

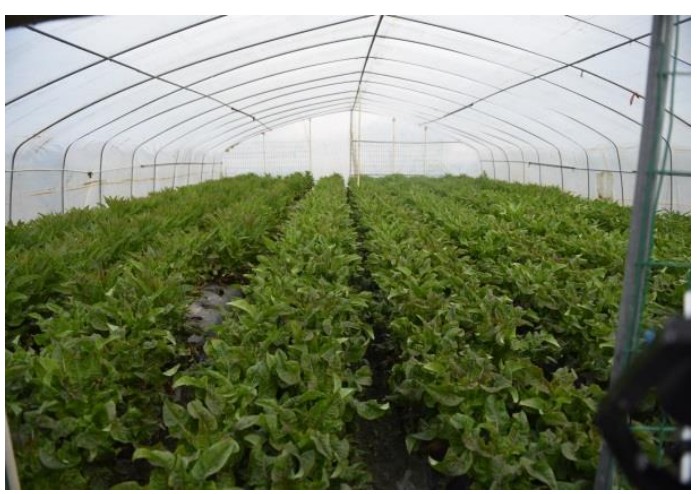

(e)

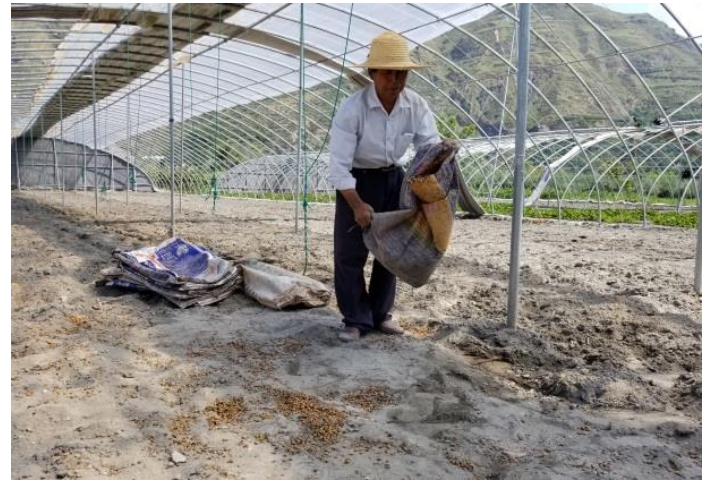

(d)

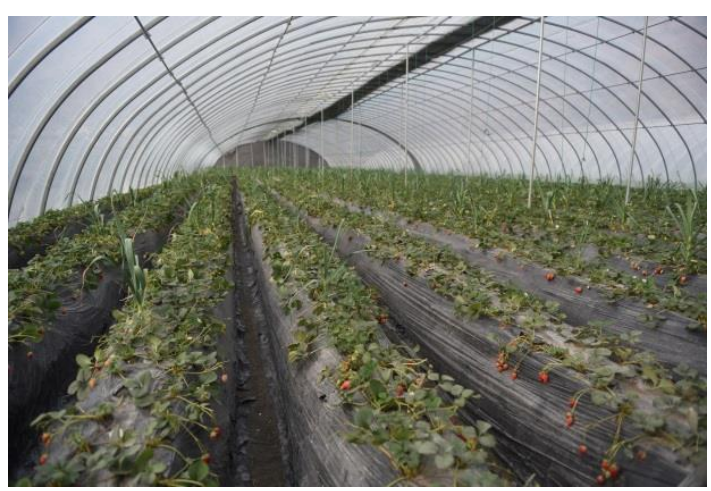

(f)

Figure 9. Greenhouse agriculture on DFWSL: $(\mathbf{a}, \mathbf{b})$ exteriors of greenhouse on DFWSL; $(\mathbf{c}, \mathbf{d})$ land consolidation and fertilization; (e,f) vegetable (lettuce) and fruit (strawberry).

\subsection{Relationship between Population Change and Land Use and Transformation}

Different schools of thought exist regarding the relationship between population growth and land use type transformation. One opinion is that population increase is directly related to the change in the quantity of woodland and cultivated land. For example, population growth leads to a reduction in tropical forests $[74,75]$ and an increase in the demand for arable land, thus causing excessive reclamation of agricultural land, serious land degradation, and related environmental problems [76]. As urbanization proceeds, population growth can cause a sharp decline in the quantity of arable land and an increase in the quantity of construction land [77]. Another opinion is that the increase in population is not related to land use or transformation; in particular, there is no obvious correlation between population growth and the increase or decrease in woodland and cultivated land [78]. Zhu [79] studied land use changes in areas surrounding the Bohai region of China and found that population growth did not lead to any increase in cultivated land from 1985 to 1995.

The development and use of DFWSL, especially for newly formed lands, are subject to fluctuations due to their instability and vulnerability. Land use type changes are greatly affected by natural disasters. For instance, a flat DFWSL might be used as arable land or construction land; however, owing to certain risks, it must instead be used as water and soil conservation forest. Areas seldom affected by natural conditions are often subject to greater volatility due to strategic policies $[70,80]$. Under these conditions, woodland is transformed into cultivated land, which is in turn transformed into construction land and may eventually become woodland or cultivated land. In mountainous areas, the growth and migration of populations are oriented to suitable and safe environments. Therefore, there is no direct and obvious correlation between the change of land-use type and population change in DFWSL. The complex relationship among them is co-determined by land use scales, policy shifts, and human 
decision-making. Based on our findings from the field investigation in the Wudu District, population growth leads to different population distributions that affect further development of land as cultivated land, woodland or construction land. For example, if the population in an area is concentrated and the land is resilient, the area may develop into residential areas and towns, while ecologically sensitive areas would be transformed into cultivated land or woodland. Therefore, changes in land use, especially changes in the quantity of arable land, may result in population increase, population decrease, or unchanged population, indicating no direct or universal correlation.

\subsection{Limitations and Recommendations}

Although the development and use of DFWSL areas have brought substantial ecological, economic, and social benefits to local farmers, certain limitations still exist. The location of the Wudu District in the gully region of the Loess Plateau, with the presence of mountains, rivers and ravines, frequent natural disasters, unfavorable temporal and spatial distributions of rainfall, and poor irrigation, have limited development and sustainability of agriculture, resulting in high cost and low income from agricultural production. Additionally, financial assistance is insufficient in Wudu District. Lack of investment and agricultural infrastructure, coupled with lack of knowledge and awareness of market competition among farmers, and the lack of new technology and systematic development, makes it difficult to popularize new crops. Although efficient multi-dimensional eco-agriculture and greenhouse technology have been promoted in some regions, current agricultural industrialization continues to lag. Channels for farmers to increase their incomes are not diversified; agricultural products remain at the roughly processed stage without packaging, thus making it challenging for farmers to increase their incomes.

To cope with these limitations, it is recommended to strengthen the construction of industrial bases, expand the scale of production, develop trade and export-oriented agriculture, and upgrade industrial production. It is also suggested that local governments continue the construction of leading industrial bases for fruits, vegetables and livestock, formulate construction standards for industrial bases, and focus on concentrated development. Furthermore, the government should provide support for agricultural cooperatives in terms of technical help, policy, and financial aid. For example, the government should help train various types of agricultural brokers who can give training and guidance to farmers and expand the scope of agriculture development. Additionally, the administration should actively explore new approaches of land circulation in accordance with the principle of "lawful, voluntary and paid" and modify policies to upgrade land circulation.

Local governments should also pursue brand strategies and promote unique local agriculture. The specialties of Wudu District, such as peppers and olives, need resource integration to dominate the market. Efforts should be made to accelerate the establishment and improvement of a standardization system for pollution-free agricultural products and organic foods. Additionally, the formulation and implementation of standards should be strengthened, while continuing to introduce new crop varieties and technologies, and to update knowledge. To help leading enterprises building brand awareness, an increase in investments and active participation in various agricultural product competitions must be encouraged. Winning awards and appraisal can improve the popularity of products. The government should also organize and coordinate the development of local agriculture. For example, the government should classify local specialties such as peppercorns, walnuts, and olives, integrate brands, increase production processing, adopt more technologies, and strengthen resource management.

The exploitation and protection of DFWSL are contradictory. In debris flow active areas, it is imperative to increase awareness and strengthen the ability for disaster prevention and relief. At the same time, it is significant to enhance cultural literacy, strictly observe conservation, and ensure rapid and sustainable socioeconomic development. With these two measures, an overall improvement in the economy, life quality, and environment can be achieved, and an ecological-economic comprehensive development zone can be built. 


\section{Conclusions}

The development and use of DFWSL areas provide potential for relieving conflicts between humans and land in environmentally fragile mountainous areas and address the dilemma of land protection and sustainable development. This study was conducted in Wudu District, which is a typical model for the use of DFWSL. The trend of land use and transformation from 2005 to 2015 was analyzed and the results indicated that the land use type changes from 2005 to 2010 and from 2010 to 2015 was from cultivated land to grassland and construction land. However, the rate and scale of change between 2005 and 2010 were far lower than those during 2010-2015. Additionally, the conversion rate of cultivated land to construction land during 2010-2015 (6.87\%) was more than 60 times that of 2005-2010 (0.11\%). Finally, the area of construction land increased by $13.38533 \mathrm{~km}^{2}$ from 2005 to 2015, accounting for $25.64 \%$ of the entire construction land area.

Natural driving forces behind changes in land use type are natural disasters and include mudslides, landslides, and earthquakes, while anthropogenic factors are mainly the transformation of national policies and strategies. Moreover, in terms of land-use change in the debris flow area, the natural driving force has a decisive effect on the type of the initial development of DFWSL areas, while national policies or strategies in different periods only affect the direction of transformation in that specific period.

Author Contributions: S.H. and D.W. conceived and designed the framework of this article; S.H. and P.Z. collected and analyzed the data; All the authors contributed to the writing of this paper.

Funding: This work was supported by the National Natural Science Foundation of China (Grant No. 41790434) and the National Sci-tech Support Plan of China (2014BAL05B01).

Acknowledgments: We are grateful for the comments and criticisms of an early version of this manuscript by our colleagues and the journal's reviewers.

Conflicts of Interest: The authors declare no conflict of interest.

\section{References}

1. Fu, B. Ecosystem Services and Ecological Security; Higher Education Press: Beijing, China, 2013.

2. Wang, X.; Bao, Y. Study on the methods of dynamic change of Land use. Adv. Geogr. 1999, 181, 81-87.

3. Lesschen, J.P.; Verburg, P.H.; Staal, S.J. Statistical Methods for Analysing the Spatial Dimension of Changes in Land Use and Farming Systems; Wageningen University: Wageningen, The Netherlands, 2005.

4. Chen, Y.; Yang, P. New progress in the study of land use/land cover change in the world. Econ. Geogr. 2001, 21, 95-100.

5. Stern, P.C.; Young, O.R.; Druckman, D. Global Environmental Change: Understanding the Human Dimension; National Research Council: Washington, DC, USA, 1992.

6. Tumer, B.L.; Meyer, W.B.; Skole, D.L. Global land use/land cover change: Toward an integrated program of study. Ambio 1994, 23, 91-95.

7. Lawler, J.J.; Lewis, D.J.; Nelson, E.; Andrew, J.P.; Stephen, P.; John, C.; Withey, D.P.; Helmers, S.M.; Derric, P.; Volker, C.R. Projected land-use change impacts on ecosystem services in the United States. Proc. Natl. Acad. Sci. USA 2014, 111, 7492-7497. [CrossRef] [PubMed]

8. Curebal, I.; Efe, R.; Soykan, A.; Sonmez, S. Impacts of anthropogenic factors on land degradation during the anthropocene in Turkey. J. Environ. Biol. 2015, 36, 51-58. [PubMed]

9. Pan, H.; Deal, B.; Chen, Y.; Geoffrey, H. A Reassessment of urban structure and land-use patterns: Distance to CBD or network-based? Evidence from Chicago. Reg. Sci. Urban Econ. 2018, 70, 215-228. [CrossRef]

10. Brovkin, V.; Boysen, L.; Arora, V.K.; Boisier, J.P.; Cadule, P.; Chini, L.; Claussen, M.; Friedlingstein, P.; Gayler, V.; van den Hurk, B.J.J.M.; et al. Effect of anthropogenic land-use and land-cover changes on climate and land carbon storage in CMIP5 projections for the twenty-first century. J. Clim. 2013, 26, 6859-6881. [CrossRef]

11. Wu, K.Y.; Ye, X.Y.; Qi, Z.F.; Zhang, H. Impacts of land use/land cover change and socioeconomic development on regional ecosystem services: The case of fast-growing Hangzhou metropolitan area, China. Cities 2013, 31, 276-284. [CrossRef] 
12. Vanloocke, A. The Impact of Land-Use And Global Change on Water-Related Agro-Ecosystem Services in the Midwest US. Ph.D. Thesis, University of Illinois at Urbana-Champaign, Champaign, IL, USA, 2012.

13. Luyssaert, S.; Jammet, M.; Stoy, P.C.; Stephan, E.; Julia, P.; Eric, C.; Galina, C.; Axel, D.; KarlHeinz, E.; Morgan, F.; et al. Land management and land-cover change have impacts of similar magnitude on surface temperature. Nat. Clim. Chang. 2014, 4, 389-393. [CrossRef]

14. Turner, B.L.; Skole, D.; Sanderson, S.; Fischer, G.; Fresco, L.; Leemans, R. Land-Use and Land-Cover Change: Science/Research Plan; International Geosphere-Biosphere Programme: Stockholm, Sweden, 1995.

15. Alexandratos, N.; Bruinsma, J. World Agriculture towards 2030/2050: The 2012 Revision; ESA Working paper Rome; FAO: Rome, Italy, 2012.

16. Schmitz, C.; van Meijl, H.; Kyle, P.; Nelson, G.C.; Fujimori, S.; Gurgel, A.; Havlik, P.; Heyhoe, E.; d'Croz, D.M.; Popp, A.; et al. Land-use change trajectories up to 2050: Insights from a global agro-economic model comparison. Agric. Econ. 2014, 45, 69-84. [CrossRef]

17. Bajzelj, B.; Richards, K.S.; Allwood, J.M.; Smith, P.; Dennis, J.S.; Curmi, E.; Gilligan, C.A. Importance of food-demand management for climate mitigation. Nat. Clim. Chang. 2014, 4, 924-929. [CrossRef]

18. Benton, T.G.; Bailey, R.; Froggatt, A.; King, R.; Lee, B.; Wellesley, L. Designing sustainable landuse in a $1.5^{\circ}$ world: The complexities of projecting multiple ecosystem services from land. Curr. Opin. Environ. Sustain. 2018, 31, 88-95. [CrossRef]

19. Jiang, Z. Strategic framework for sustainable use of land resources in China. Rural Econ. Technol. 2003, 13-16, (In Chinese with English Abstract).

20. Wang, X.H.; Zheng, D.; Shen, Y.C. Land use change and its driving forces on the Tibetan Plateau during 1990-2000. Catena 2008, 72, 56-66. [CrossRef]

21. Li, X.Y.; Ma, Y.J.; Xu, H.Y.; Wang, J.H.; Zhang, D.S. Impact of landuse and land cover change on environmental degradation in Lake Qinghai watershed, northeast Qinghai-Tibet Plateau. Land Degrad. Dev. 2010, 20, 69-83. [CrossRef]

22. Glasby, G.P. Sustainable development: The need for a new paradigm. Environ. Dev. Sustain. 2002, 4, 333-345. [CrossRef]

23. Cao, S.; Liu, Y.; Yu, Z. China's successes at combating desertification provide roadmap for other nations. Environ. Sci. Policy Sustain. Dev. 2018, 60, 16-24. [CrossRef]

24. Liu, H.; Liu, Y.; Bi, R.; Xu, Y.; Wang, S. Reuse type judgment of mining wasteland based on land use competitiveness. Trans. Chin. Soc. Agric. Eng. 2016, 32, 258-266.

25. Chen, T.T.; Peng, L.; Liu, S.Q.; Wang, Q. Land cover change in different altitudes of Guizhou-Guangxi karst mountain area, China: Patterns and drivers. J. Mt. Sci. 2017, 14. [CrossRef]

26. Zhang, J.; He, C.; Chen, L.; Cao, X. Improving food security in China by taking advantage of marginal and degraded lands. J. Clean Prod. 2018, 171, 1020-1030. [CrossRef]

27. Cai, Y. It is possible to turn unused land into construction land. Chin. Land 2010, 8, 27-31.

28. Dorn, R.I. Desert rock coatings. In Geomorphology of Desert Environments; Springer: Dordrecht, The Netherlands, 2009; pp. 153-186.

29. Frankel, K.; Dolan, J. Characterizing arid region alluvial fan roughness with airborne laser swath mapping digital topographic data. J. Geophys. Res. 2007, 112. [CrossRef]

30. Blair, T.; McPherson, J. Processes and forms of alluvial fans. In Geomorphology of Desert Environments; Parsons, A., Abrahams, A., Eds.; Springer: New York, NY, USA, 2009; pp. 413-467.

31. Marcato, G.; Bossi, G.; Rivelli, F.; Borgatti, L. Debris flood hazard documentation and mitigation on the Tilcara alluvial fan (Quebrada de Humahuaca, Jujuy province, North-West Argentina). Nat. Hazard Earth Syst. Sci. 2012, 12, 1873-1882. [CrossRef]

32. Scheinert, C.; Wasklewicz, T.; Staley, D. Alluvial fan dynamics-Revisiting the field. Geogr. Compass 2012, 6, 752-775. [CrossRef]

33. Blackwelder, E. Desert plains. J. Geol. 1931, 39, 133-140. [CrossRef]

34. Bull, W.B. The alluvial fan environment. Prog. Phys. Geogr. 1977, 1, 222-270. [CrossRef]

35. Tsujimoto, Y.; Inusah, B.; Katsura, K.; Fuseini, A.; Dogbe, W.; Zakaria, A.I.; Yoichi, F.; Masato, O.; Jun-Ichi, S. The effect of sulfur fertilization on rice yields and nitrogen use efficiency in a floodplain ecosystem of northern ghana. Field Crop Res. 2017, 211, 155-164. [CrossRef]

36. Haas, T.D.; Densmore, A.L.; Stoffel, M.; Suwa, H.; Imaizumi, F.; Ballesteros-Cánovas, J.A.; Wasklewiczf, T. Avulsions and the spatio-temporal evolution of debris-flow fans. Earth Sci. Rev. 2018, 177, 53-57. [CrossRef] 
37. Staley, D.M.; Wasklewicz, T.A.; Blaszczynsky, J.S. Surficial patterns of debris-flow deposition on alluvial fans in Death Valley, CA using airborne laser swath mapping data. Geomorphology 2006, 74, 152-163. [CrossRef]

38. Cavalli, M.; Marchi, L. Characterization of the surface morphology of an alpine alluvial fan using airborne LiDAR. Nat. Hazard Earth Syst. Sci. 2008, 8, 323-333. [CrossRef]

39. Wang, D.; Cui, P.; Zhu, B.; Wei, F. Characteristics of High Sand flow and improvement of debris flow waste-shoal land in Jiangjia gully, Yunnan, China. Mt. Res. 2003, 6, 745-751.

40. Bull, W.B. Geomorphology of Segmented Alluvial Fans in Western Fresno County, California; US Government Printing Office: Washington, DC, USA, 1964.

41. Cui, P.; Ge, Y.; Zhuang, J.; Wang, D. Soil evolution features of debris flow waste-shoal land. J. Mt. Sci. 2009, 6, 181-188. [CrossRef]

42. Sancho, C.; Pena, J.L.; Rivelli, F.; Rhodes, E.; Munoz, A. Geomorphological evolution of the Tilcara alluvial fan (Jujuy Province, NW Argentina): Tectonic implications and palaeoenvironmental considerations. J. South Am. Earth Sci. 2008, 26, 68-77. [CrossRef]

43. Okunishi, K.; Suwa, H. Assessment of debris-flow hazards of alluvial fans. Nat. Hazards 2001, 23, $259-269$. [CrossRef]

44. Curry, G.N.; Koczberski, G.; Selwood, J. Cashing out, cashing in: Rural change on the south coast of Western Australia. Aust. Geogr. 2001, 32, 109-124. [CrossRef]

45. Petit, S. The dimensions of land use change in rural landscapes: Lessons learnt from the GB Countryside Surveys. J. Environ. Manag. 2009, 90, 2851-2856. [CrossRef] [PubMed]

46. Rudel, T.K. Tree farms: Driving forces and regional patterns in the global expansion of forest plantations. Land Use Policy 2009, 26, 545-550. [CrossRef]

47. Poyatos, R.; Latron, J.; Llorens, P. Land use and land cover change after agricultural abandonment: The case of a Mediterranean mountain area (Catalan Pre-Pyrenees). Mt. Res. Dev. 2003, 23, 362-368. [CrossRef]

48. Zhou, Z. Landscape changes in a rural area in China. Landsc. Urban Plan. 2000, 47, 33-38.

49. Burgi, M.; Russell, E.W.B. Integrative methods to study landscape changes. Land Use Policy 2001, 18, 9-16. [CrossRef]

50. Weng, Q.H. Land use change analysis in the Zhujiang Delta of China using satellite remote sensing, GIS and stochastic modeling. J. Environ. Manag. 2002, 64, 273-284. [CrossRef]

51. Chen, L.D.; Messing, I.; Zhang, S.R.; Fu, B.J.; Ledin, S. Land use evaluation and scenario analysis towards sustainable planning on the Loess Plateau in China-case study in a small catchment. Catena 2003, 54, 303-316. [CrossRef]

52. Lu, L.; Li, X.; Cheng, G.D. Landscape evolution in the middle Heihe River Basin of North-West China during the last decade. J. Arid Environ. 2003, 53, 395-408. [CrossRef]

53. Jia, B.Q.; Zhang, Z.Q.; Ci, L.J.; Ren, Y.P.; Pan, B.R.; Zhang, Z. Oasis land-use dynamics and its influence on the oasis environment in Xinjiang, China. J. Arid Environ. 2004, 56, 11-26. [CrossRef]

54. Zhao, H.L.; Zhao, X.Y.; Zhou, R.L.; Zhang, T.H.; Drake, S. Desertification processes due to heavy grazing in sandy rangeland, Inner Mongolia. J. Arid Environ. 2005, 62, 309-319. [CrossRef]

55. Liu, J.; Huang, J.; Ou, G.; Fan, J. The developing potentiality of slope farmland on the alluvial fans of debris flow in the midstream of Bailongjiang River. Res. Soil Water Conserv. 2011, 18, 92-96.

56. Future Earth. Future Earth 2025 Vision; Future Earth Interim Secretariat: Paris, France, 2014.

57. Liu, Y. Strategies to Guarantee Land Resources Safety in China. Proc. Chin. Acad. Sci. 2006, 21, 379-384.

58. Records of Wudu County, Gansu Province, China. In Compilation Committee of Local Records of Wudu County; Sanlian Bookstore: Beijing, China, 1998.

59. Longley, P.A. Geography: Will development in urban remote sensing and GIS lead to better urban geography? Prog. Hum. Geogr. 2002, 26, 231-239. [CrossRef]

60. Braimoh, A.K. Random and systematic land-cover transitions in northern Ghana. Agric. Ecosyst. Environ. 2006, 113, 254-263. [CrossRef]

61. Wang, J.; Fu, B. The impact of land use on spatial and temporal distribution of soil moisture on the Loess Plateau. Acta Geogr. Sin. 2000, 55, 84-91.

62. Huang, Z.; Yu, Y. Distribution and Developmental characteristics of debris flow in Longnan area of the Upper reaches in Yangtze River. People Yangtze River 1998, 29, 42-44.

63. Ning, N.; Tian, L.; Zhang, P.; Qi, S.; Ma, J. Risk Assessment of debris flow in Wudu area, South Gansu Province, China. Mt. Res. 2013, 31, 601-609. 
64. Wang, D.; Meng, X.; Guo, P.; Guo, J.; Tan, L. Dynamic changes of land use before and after returning farmland to forest in Wudu, Gansu Province, China. Guizhou Agric. Sci. 2012, 40, $227-229$.

65. Nagashima, K.; Sands, R.; Whyte, A.G.D.; Bilek, E.M.; Nobukazu, N. Regional landscape change as a consequence of plantation forestry expansion: An example in the Nelson rejoin, New Zealand. For. Ecol. Manag. 2002, 163, 245-261. [CrossRef]

66. Liu, Y.; Li, Y. Revitalize the world's countryside. Nature 2017, 548, 275-277. [CrossRef] [PubMed]

67. Shi, Z.; Deng, W.; Zhang, S. Spatio-temporal pattern changes of land space in hengduan mountains during 1990-2015. J. Geogr. Sci. 2018, 28, 529-542. [CrossRef]

68. Yamanaka, H.; Yoshida, M.; Arita, K. Terrace landform and Quaternary deposit around Pokhara Valley, central Nepal. J. Nepal Geol. Soc. 1982, 2, 95-112.

69. Gautam, P.; Panta, S.R.; Ando, H. Mapping of subsurface karst structure with gamma ray and electrical resistivity profiles: A case study from Pokhara valley, central Nepal. J. Appl. Geophys. 2000, 45, 97-110. [CrossRef]

70. Rimal, B.; Baral, H.; Stork, N.; Kiran, P.; Sushila, R. Growing City and Rapid Land Use Transition: Assessing Multiple Hazards and Risks in the Pokhara Valley, Nepal. Land 2015, 4, 957-978. [CrossRef]

71. Tilman, D.; Hill, J.; Lehman, C. Carbon-negative biofuels from low-input high-diversity grassland biomass. Science 2006, 314, 1598-1600. [CrossRef] [PubMed]

72. Robertson, G.P.; Dale, V.H.; Doering, O.C.; Hamburg, S.P.; Melillo, J.M.; Wander, M.M.; Parton, W.J.; Adler, P.A.; Barney, J.N.; Cruse, R.M.; et al. Sustainable biofuels redux. Science 2008, 322, 49-50. [CrossRef] [PubMed]

73. Caserta, G. Reclamation of abandoned lands in Mediterranean countries through the contribution of biomass and other renewable energy sources. A metodological proposal. In Proceedings of the Conference on Responsible Coastal Zone Management; 2000; pp. 275-280. Available online: https:/ / www.researchgate.net/ publication/295998952_Reclamation_of_abandoned_lands_in_Mediterranean_countries_through_the_ contribution_of_biomass_and_other_renewable_energy_sources_A_metodological_proposal (accessed on 3 August 2018).

74. Kammerbauer, J.; Ardon, C. Land use dynamics and landscape change pattern in a typical watershed in the hillside region of central Honduras. Agric. Ecosyst. Environ. 1999, 75, 93-100. [CrossRef]

75. Verburg, P.H.; Veldkamp, T.A.; Bouma, J. Land use change under conditions of high population pressure: The case of Java. Glob. Environ. Chang. 1999, 9, 303-312. [CrossRef]

76. Nemes, I. Land reclamation works applied in the amelioration perimeter in territorial agrarian fond otelec-uivar, Timiş County, Romania. Res. J. Agric. Sci. 2009, 41, 472-476.

77. Xu, Y.; Tang, Q.; Fan, J.; Bennett, S.J.; Li, Y. Assessing construction land potential and its spatial pattern in china. Landsc. Urban. Plan. 2011, 103, 207-216. [CrossRef]

78. Lambin, E.F.; Turner, B.L.; Geist, H.J.; Samuel, B.A.; Arild, A.; John, W.B.; Oliver, T.C.; Rodolfo, D.; Günther, F.; Carl, F; i et al. The causes of land-use and land-cover change: Moving beyond the myths. Glob. Environ. Chang. 2001, 11, 261-269. [CrossRef]

79. Zhu, H.; He, S.; Zhang, M. Driving forces analysis of land use change in Bohai Rim. Geogr. Res. 2001, 20, 669-678.

80. Deal, B.; Pan, H. Discerning and Addressing Environmental Failures in Policy Scenarios Using Planning Support System (PSS) Technologies. Sustainability 2016, 9, 13. [CrossRef]

(C) 2018 by the authors. Licensee MDPI, Basel, Switzerland. This article is an open access article distributed under the terms and conditions of the Creative Commons Attribution (CC BY) license (http://creativecommons.org/licenses/by/4.0/). 